\title{
Induced antimicrobial activity in heat-treated woodchips inhibits the activity of the invasive plant pathogen Phytophthora ramorum
}

\author{
Mina Kalantarzadeh ${ }^{1,2,3}$, Dulcie Mulholland ${ }^{2}$, Frans De Leij ${ }^{1}$, Joan F. Webber ${ }^{3}$ \\ ${ }^{1}$ Department of Biosciences, Faculty of Health and Medical Sciences, ${ }^{2}$ Department of Chemistry, \\ University of Surrey, Guildford, England; \\ ${ }^{3}$ Forest Research, Alice Holt lodge, Farnham, Surrey, GU10 4LH, UK
}

Corresponding author: joan.webber@forestry.gsi.gov.uk

Disease suppression, EU1 lineage, Larix, rhododendron, phenolics, resin acids

Running title: Woodbased compounds inhibit $P$. ramorum

\begin{abstract}
We investigated the antimicrobial activity of heat-treated woodchips of three woody host species against the invasive oomycete plant pathogen Phytophthora ramorum to assess the potential of heated woodchips for disease suppression. Results demonstrated that heat-treated pine (Pinus sylvestris), Japanese larch (Larix kaempferi) and rhododendron (Rhododendron ponticum) woodchips inhibited the recovery of $P$. ramorum spores and mycelium compared with similar material that had only been air-dried. Effects were most evident with pine and larch; inhibition was maintained even when larch woodchips were diluted with soil. In vitro assays using methanol crude extracts from woodchips of the three species showed they all had an inhibitory effect on $P$. ramorum zoospores and reduced chlamydospore germination compared with air-dried wood extracts. Chemical analysis of the extracts revealed several induced compounds were present but in different concentrations for each species. This article has been accepted for publication and undergone full peer review but has not been through the copyediting, typesetting, pagination and proofreading process, which may lead to differences between this version and the Version of Record. Please cite this article as doi: 10.1111/ppa.13010
\end{abstract}

This article is protected by copyright. All rights reserved. 
Coniferaldehyde was the most active inhibitory against spores and mycelium, whilst the dominant resin acids, dehydroabietic and abietic acid, decreased the minimum inhibitory concentration of phenolic compounds tested against $P$. ramorum but were ineffective when used alone. An array of compounds, including dehydroabietic acid, methyl abietate, $\alpha$-pinene and 3-carene, occurred at elevated levels in the living tissue of Japanese larch bark attacked by P. ramorum. These compounds may be part of the induced resistance response of larch to P. ramorum. Results of a field trial using heat-treated and air-dried woodchips were consistent with the crude extract bioassay results, suggesting that heat-treated woody materials have potential to reduce the survival of $P$. ramorum under natural conditions.

\section{Introduction}

The oomycete Phytophthora ramorum Werres, De Cock \& Man in 't Veld is the causal agent of 'sudden oak death' in the western United States where the disease has resulted in extensive mortality of oaks and tanoaks since the early 1990s (Rizzo et al. 2002; Frankel 2008). After its formal description in 2001 (Werres et al. 2001) P. ramorum was quickly reported from a number of countries in Europe. In the UK, the first finding was made in a nursery in 2002 with further discoveries in the wider environment made soon after (Brasier et al. 2004a).

'Ramorum dieback' as it was first known in the UK, initially caused damage to a large number of ornamental and woody shrubs with only occasional impacts on broadleaf tree species such as beech (Fagus sylvatica L.) and some non-native oak species (Brasier et al. 2004b; Tracey 2009). In 2009, P. ramorum was unexpectedly found infecting Japanese larch (Larix kaempferi Lamb. Carr.) (Webber et al. 2010). Since then it has caused widespread mortality in plantation grown larch in many parts of the UK and Ireland (Brasier and Webber 2010, O'Hanlan et al. 2017). As a quarantine organism, $P$. ramorum control is mandatory in the UK and involves the early detection and removal of certain hosts, known as sporulating hosts, which generate huge numbers of spores (mainly sporangia and zoospores) when leaf and shoot tissue are infected. Initially the main sporulating host was found to be

This article is protected by copyright. All rights reserved. 
rhododendron (Denman et al. 2005; Turner et al. 2005) and a programme of rhododendron clearance was launched by Defra in 2002 to control ramorum dieback of ornamentals in the UK (Defra 2008). However, the discovery that infected foliage of Japanese larch produced huge numbers of P. ramorum spores (Webber et al. 2010; Harris \& Webber 2017) led to a major redirection of control efforts. As a consequence, millions of infected larch trees have been felled under Statutory Plant Health Notices, with initially 2,400 hectares felled or awaiting felling in 2009 rising to a total of more 20,000 hectares by 2017 (Webber and Brasier 2018).

Although removal of sporulating hosts such as infected larch and rhododendron is the accepted strategy for disease control (Sansford et al. 2009), it introduces significant biosecurity and economic impacts for the forest industry and nurseries. The same applies for gardens and parks that are open to the public and specialise in ornamental plants such as rhododendron, Camellia and Pieris which can be hard-hit by $P$. ramorum (Defra 2008). Moreover, leaves and needles of infected shrubs and trees can remain a source of inoculum even after removal of the plants, as $P$. ramorum chlamydospores that form in such tissue appear to be able to survive and persist in soil and leaf litter for some years after clearance (Turner et al. 2005; Harris 2015 ). Disease spread via contaminated soil or leaf litter on the shoes of walkers, or tools and vehicles that operate on $P$. ramorum infested sites can also occur (Cushman et al. 2008; Webber and Rose 2008). However, as complete clearance of infested material and soil from the wider environment is usually not practical or economically viable, other approaches are needed to limit inoculum levels and reduce the potential for movement of contaminated soil and litter.

One alternative strategy to reduce the spread of infected leaf litter and contaminated soil could involve covering the soil surface with a layer of woodchips that act as a physical barrier to reduce the mobility of $P$. ramorum inoculum. This approach has been studied in the USA for $P$. ramorum infested forest paths (Goheen 2013) and recognises that if the woodchips have antimicrobial activity the benefit may extend beyond just being a physical barrier. Chemicals associated with wood derived from certain tree species have been found to reduce the survival of $P$. ramorum, and in particular some conifer species

This article is protected by copyright. All rights reserved. 
contain compounds that have high levels of antimicrobial activity (Manter et al. 2006). Heat treatment of wood is also known to be an efficient way of improving its resistance to attack from wood degrading fungi. The effectiveness of the process is not only due to the reduced moisture content but also because of enhanced bioactivity following the formation of new compounds in wood materials after heating (Esteves et al. 2008; Kamdem et al. 2002; Sundqvist 2004).

In an earlier study by Kalantarzadeh (2014), chemical analysis of heat-treated wood of Scots pine (Pinus sylvestris L.) showed the existence of several potentially antimicrobial compounds when tested against a range of bacterial pathogens of animals. Using a comparable approach, the aim of this study was to evaluate whether heat-treated wood including that sourced from host plants of $P$. ramorum showed antimicrobial activity against the pathogen and therefore might have a role in the disease management. The first objective was to assess the extent of any inhibitory activity in woodchips of Scots pine, both air-dried and heat-treated, when placed in direct contact with $P$. ramorum propagules, and then extend the assays to test rhododendron (Rhododendron ponticum L.) and Japanese larch, two major hosts of $P$. ramorum in Britain. The second objective was to undertake chemical analysis of the wood of all three species and individually test the different compounds isolated to determine if they inhibited the growth of P. ramorum. A similar analysis was also applied to Japanese larch bark in the process of being invaded by $P$. ramorum to explore the expression of any antimicrobial activity. Finally, to evaluate the strength and magnitude of any enhanced antimicrobial activity in heat-treated woodchips over an extended period, a field trial was set up with the objective of measuring the recovery of $P$. ramorum from pine, larch and rhododendron woodchips exposed to $P$. ramorum inoculum from naturally sporulating hosts over a twelve-month period.

\section{Materials and Methods}

\section{Woodchip and inoculum preparation}

Logs up to $80 \mathrm{~m}$ in length were obtained from Alice Holt Forest, Farnham, where ramorum dieback was absent. Woodchips (average dimensions of woodchips 1.0 by $1.5 \mathrm{~cm}$ ) were prepared from

This article is protected by copyright. All rights reserved. 
debarked logs of rhododendron (R. ponticum), Japanese larch (L. kaempferi) and pine (P. sylvestris), using a commercial chipper and then air-dried or heat-treated. Woodchips were dried by spreading on trays whilst incubated at $20-25^{\circ} \mathrm{C}$ for 3 days or when the moisture content was $\leq 28 \%$. Heat treatment involved loosely wrapping $100 \mathrm{~g}$ quantities in aluminium foil which were heated for 72 hours at $120^{\circ} \mathrm{C}$ in an electric oven.

Two isolates of P. ramorum were selected from the Phytophthora Culture Collection held at Forest Research, Farnham, Surrey, UK, with isolates P1578 and BRC01 cultured from infected rhododendron and Japanese larch respectively. Both were the most common genetic lineage of $P$. ramorum in Europe (EU1) and genotypes common to the British population (Grunwald et al. 2012; Harris et al. 2018). Both isolates were routinely cultured on Carrot Agar (CA) plates maintained at $20^{\circ} \mathrm{C}$ as described by Brasier and Kirk (2002). When isolations were undertaken from non-sterile material, a Phytophthora selective medium was used consisting of modified Synthetic Mucor Agar (SMA) (see Brasier and Kirk 2002).

Zoospore inoculum was prepared by growing each isolate of $P$. ramorum on 25-50 CA plates incubated under continuous artificial daylight at $18-20^{\circ} \mathrm{C}$ to encourage sporangial production. After 2 weeks, $5 \mathrm{ml}$ of sterile distilled water was added to each plate, the sporangia gently dislodged using a plastic spreader and the spore-containing liquid tipped into a sterile beaker. The sporangial suspension was refrigerated at $4^{\circ} \mathrm{C}$ for 20 minutes and returned to room temperature for 45 minutes to induce zoospore release. The zoospore concentration in each suspension was counted using a haemocytometer. The average number of zoospores was estimated from four counts and adjusted to the required concentration prior to use.

Chlamydospore inoculum was prepared using the method of Tooley and Browning (2008). A $10^{4}$ zoospore $\mathrm{ml}^{-1}$ suspension $(300 \mathrm{ml}$ ) was prepared for each isolate and transferred to a zip-lock plastic bag. Leaf disks were cut from freshly harvested and water rinsed $R$. ponticum leaves using a $6 \mathrm{~mm}$ diameter cork-borer. Two hundred leaf disks were added to each spore suspension and incubated at

This article is protected by copyright. All rights reserved. 
$18-20^{\circ} \mathrm{C}$ for 5 days to allow colonisation. Under sterile conditions, the contents of each bag were sieved and then the leaf disks rinsed with sterile water and drained with the process repeated three times. The disks were transferred onto moistened tissue in plastic containers and incubated in the dark at $20^{\circ} \mathrm{C}$. After 4 weeks, the disks contained abundant chlamydospores and their presence was confirmed by direct examination under a compound microscope.

Mycelium was prepared by adding $10 \mu$ of zoospore suspension $\left(10^{4}\right.$ zoospores $\left.\mathrm{ml}^{-1}\right)$ to each well of a 96-well micro-titre plate pre-loaded with $100 \mu \mathrm{l}$ sterile distilled water per well. The plates were incubated at $20^{\circ} \mathrm{C}$ in the dark and after 3 days mycelium formation in the wells was checked using a binocular microscope. The mycelium was then transferred to 96 -well plates pre-loaded with known concentrations of the crude extracts derived from heated or non-heated woodchips of pine, larch or rhododendron or the purified compounds (see below).

\section{Microcosm experiments using only woodchips}

In these assays, treatments consisted of pine, larch and rhododendron woodchips, either air-dried or heat-treated, each challenged with a zoospore suspension of $P$. ramorum isolate BRC01, $P$. ramorum isolate P1578, or a water control. The woodchip samples were placed in sterile McCartney bottles (1g of woodchips per bottle) and each bottle was inoculated with $1 \mathrm{ml}$ of a $10^{4}$ zoospore $\mathrm{ml}^{-1}$ suspension. Bottles were incubated at $20^{\circ} \mathrm{C}$ for 3 weeks, with ten replicate bottles for each isolate of $P$. ramorum /woodchip treatment set up. Controls were prepared in the same way, but $1 \mathrm{ml}$ of sterile water was substituted for $1 \mathrm{ml}$ of zoospore suspension. After 3 weeks, $1 \mathrm{~g}$ of woodchips was removed from each bottle, placed onto an SMA plate, incubated for 7 days at $20^{\circ} \mathrm{C}$ and then checked for any outgrowth of $P$. ramorum as an indicator of survival. The number of plates with $P$. ramorum outgrowth from the woodchips was scored. In all, four separate trials of the assay were repeated.

This article is protected by copyright. All rights reserved. 


\section{Microcosm experiments using woodchip and soil mixtures}

In these assays only larch woodchips were used in the soil mixtures, with each treatment challenged using two types of $P$. ramorum inoculum consisting of either a zoospore suspension or leaf disks permeated with chlamydospores. As before, isolates BRC01 and P1578 were used.

In the first assay, air-dried or heat-treated larch woodchips were ground into fine particles $\leq 2 \mathrm{~mm}$ in diameter and mixed thoroughly with non-sterile, but $P$. ramorum-free soil obtained from Alice Holt Forest, Farnham, Surrey. The ground wood was mixed with the soil in plastic bags in a 1:3 or 3:1 ratio (w:w) to make a total dry weight of $30 \mathrm{~g}$. After mixing, sterile water was added to water holding capacity. The bags were closed and incubated at $25^{\circ} \mathrm{C}$ for 7 days but stirred with a sterile spatula every two days. Treatments consisting of just soil or ground woodchips were also set up. Additionally, perlite was substituted for woodchips and mixed with soil in the same proportions to act as controls. A $10^{3}$ zoospores $\mathrm{ml}^{-1}$ suspension was added to each bag (10 $\mathrm{ml}$ per $30 \mathrm{~g}$ ), thoroughly mixed and the bags incubated at room temperature $\left(20^{\circ} \mathrm{C}\right)$ for 4 or 8 weeks. After incubation, four replicate $1 \mathrm{~g}$ samples of the mixture were removed from each bag, each diluted with $10 \mathrm{ml}$ sterile water and $1 \mathrm{ml}$ of the dilution spread onto SMA plates. The plates were incubated at $20^{\circ} \mathrm{C}$ for 7 days, counts of P. ramorum colonies were made and expressed as colony forming units (cfu) $\mathrm{g}^{-1}$.

In the second assay, rhododendron leaf disks permeated with $P$. ramorum chlamydospores were incorporated into a 3:1 and 1:3 ratio of heat-treated larch woodchip/soil mix as already described, again with a perlite-soil mixture acting as the control. Each mixture was set up in a plastic pot and 12 leaf disks previously colonised with $P$. ramorum were added to each pot, with three replicate pots for each treatment. The pots were maintained at room temperature $\left(20^{\circ} \mathrm{C}\right)$ for either 4 weeks or 12 weeks, after which the disks were recovered from the pots, rinsed with sterile water, placed onto SMA plates and incubated for 3 weeks at $20^{\circ} \mathrm{C}$. As before, each disk was assessed for any outgrowth of $P$. ramorum.

This article is protected by copyright. All rights reserved. 


\section{Bioassays of crude wood extracts}

Crude extracts were made from heat-treated and air-dried woodchips of pine, larch and rhododendron and tested against two types of $P$. ramorum inoculum consisting of either a zoospore suspension or leaf disks permeated with chlamydospores. As before, isolates BCR01 and P1578 were used.

Before extraction, the wood from each species was processed into fine shavings ( $c a .500 \mathrm{~g}$ for each wood type) and then either air dried or oven dried. Subsequently, crude extracts were prepared by adding laboratory grade methanol to woodchips in a 5:1 ratio. Extractions were set up in triplicate with woodchips left to soak for 24 hours at room temperature on a roller shaker (SPIRAMAX 5, Denley Instrument Ltd.). The woodchips were then removed, and crude extracts were obtained by evaporating off the methanol. The crude extracts were finally decanted into sterile vials and stored at $4^{\circ} \mathrm{C}$ until used. For assays, each crude extract was dissolved in acetone at a concentration of $50 \mathrm{mg}$ $\mathrm{ml}^{-1}$ to create a standard stock solution.

The first assay tested the effect of diluted crude extracts on zoospores. Ninetysix-well micro-titre plates were pre-loaded with $9.6 \mathrm{ml}$ carrot broth $\left(250 \mathrm{~g}\right.$ carrots $\mathrm{L}^{-1}$ of distilled water, boiled for an hour and filtered through cheese cloth) and $0.4 \mathrm{ml}$ of a dilution series of the crude extract stock solutions (equating to $25,12.5,6.25 \mathrm{mg}$ extract $\mathrm{ml}^{-1}$ ) added into the broth. The micro-titre plates were left in a laminar flow cabinet for 5 hours to allow the acetone to evaporate. Three replicates were prepared for each extract concentration. Control wells received only acetone and carrot broth. Each well was inoculated with $5 \mu \mathrm{l}$ of a $10^{4} \mathrm{ml}^{-1}$ zoospore suspension before the plates were incubated at $20^{\circ} \mathrm{C}$ for 24 hours. To determine if the extracts were inhibitory, $20 \mu \mathrm{l}$ from each well was spotted onto CA plates and incubated for 24-48 hours. Inoculum spots with no growth were rated as inhibitory.

The second assay tested the effect of the crude extracts on chlamydospore impregnated rhododendron leaf disks using six-well plates. Each individual well in the six-well plates was loaded with six leaf disks and $1 \mathrm{ml}$ of sterile water which contained $10 \mathrm{mg}$ of crude extract. Each crude extract that was tested was replicated in two wells. To ensure good contact between the chlamydospores and the

This article is protected by copyright. All rights reserved. 
extract, the six well plates were incubated for 48 hours on a platform shaker at room temperature. After incubation, the disks were removed with a pair of sterilised forceps, rinsed in sterile water for $1 \mathrm{~h}$ and placed onto SMA plates. The plates were incubated for 5 days and the presence/absence of outgrowth of $P$. ramorum recorded for each disk. The entire assay was undertaken twice, and overall means calculated from the combined data.

\section{Bioassays using specific antimicrobial compounds}

Individual compounds originally derived from heat-treated pine wood were tested by preparing a dilution series of each compound (range 20 to $0.009 \mathrm{mmol}$ ) in dimethyl sulfoxide (DMSO). The compounds previously identified as coniferaldehyde, acetovanillon and vanillin (Kalantarzadeh 2014) were compared against the crude extract from pine.

Each diluted compound was added to a well, in 96-well plates, each well containing zoospores, chlamydospores or mycelium. All treatments were replicated three times. Plates were incubated at $20^{\circ} \mathrm{C}$ for $24 \mathrm{~h}$ for zoospores, and $48 \mathrm{~h}$ for chlamydospores and mycelia, then the contents of each well was placed onto a SMA plate and incubated for 5 days at $20^{\circ} \mathrm{C}$ to assess for any outgrowth of $P$. ramorum. The concentration at which no growth occurred was recorded as the minimum inhibitory concentration (MIC). To test whether the addition of resin acids lowered the MIC of the three compounds, the assay was repeated in combination with $20 \mathrm{mmol}$ of the resin acids dehydroabietic acid (DHAA), abietic acid (AA) and pimaric acid (PA). Activity of resin acids was tested only against zoospores of $P$. ramorum isolates BRC01 and P1578.

\section{Isolation, purification and identification of bioactive compounds}

Gas chromatography mass spectrometry (GCMS), carried out with Agilent Technologies 7890A, GC system fitted with an Agilent Technologies 5975 inert XL EI/CI MSD triple axis detector, was used to analyse the methanol crude extracts of heat-treated wood samples. Samples were dissolved in chloroform or methanol (depending on solubility), $2 \mu 1$ of each sample injected and volatised at $250^{\circ} \mathrm{C}$

This article is protected by copyright. All rights reserved. 
for 25 minutes using the HP-5-MS column $(30 \mathrm{~m} \times 250 \mu \mathrm{m} \times 0.25 \mu \mathrm{m})$ which was heated initially to $50^{\circ} \mathrm{C}$ for 3 minutes and then to $250^{\circ} \mathrm{C}$ for 1 minute, and then the temperature held for 30 minutes.

To isolate and purify different bioactive compounds from woodchips, a methanol extract from pine woodchips was reduced to $30 \mathrm{~g}$ of crude, dissolved in $100 \%$ methanol and mixed with $10 \mathrm{~g}$ silica gel (Merck 9385), followed by a drying step in a fume hood for 2 days. A $50 \mathrm{~cm}$ cylindrical gravity column with a $4 \mathrm{~cm}$ internal diameter was packed using a slurry of silica gel and $100 \%$ hexane. The dried crude extract/silica gel was added to the packed column, eluted using $100 \%$ dichloromethane $\left(\mathrm{CH}_{2} \mathrm{Cl}_{2}\right)$ and collected in $75 \mathrm{ml}$ portions giving around 260 fractions. Thin layer chromatography (TLC) was used to analyse the purity of each fraction. Fractions that had similar TLC bands were subsequently combined. A solution of $p$-anisaldehyde, sulphuric acid and cold methanol (1.5:2.5:96) was used to visualise the TLC spots. Combined fractions were further purified using small gravity columns ( $1 \mathrm{~cm}$ internal diameter) or preparative TLC plates and each purified product was identified using nuclear magnetic resonance (NMR) spectroscopic techniques. The NMR spectra were recorded at room temperature using either a 300 or $500 \mathrm{MHz}$ Bruker AVANCE NMR spectrometer.

To identify potentially antimicrobial compounds from the bark of Japanese larch, material was collected from a naturally infected Japanese larch tree showing red and brown discolouration of the phloem typical of a P. ramorum colonised lesion and a GCMS analysis of different regions in and around the lesions was performed, following the preparation of refined dichloromethane $\left(\mathrm{CH}_{2} \mathrm{Cl}_{2}\right)$ extracts of these regions as described above. The sample bark regions processed as $\mathrm{CH}_{2} \mathrm{Cl}_{2}$ extracts were: white tissue (not yet invaded), red tissue (indicating a response to $P$. ramorum but where the pathogen could not be detected either by isolation or PCR-based detection), dark brown tissue behind the red tissue margin (which usually yielded the pathogen when culturing or was PCR-positive for $P$. ramorum). Apart from these samples, a $\mathrm{CH}_{2} \mathrm{Cl}_{2}$ crude extract of the white phloem tissue from a healthy Japanese tree was also included for comparison.

This article is protected by copyright. All rights reserved. 


\section{Field assessments}

A trial was set up to compare the potential of air-dried and heat-treated woodchips derived from the natural hosts of $P$. ramorum (rhododendron and Japanese larch) to inhibit the growth of $P$. ramorum under field conditions. This involved exposure to variable inoculum loads of sporangia and zoospores.

In November 2011, a location at Forestry Commission Largin Wood, Cornwall (OS Grid Reference: SX167647), was chosen as the field trial site because of its history of natural P. ramorum infection. Prior to the trial setup, $R$. ponticum foliage and soil samples were collected from three different locations at the site and checked for the presence of P. ramorum by plating onto SMA. As both foliage and soil samples at all three locations were positive for P. ramorum, fine mesh bags filled with either heat-treated and air-dried woodchips of pine, larch and rhododendron were placed on the litter layer at each location and sampled after 4, 8, 12, 20 and 52 weeks. Each bag contained $150 \mathrm{~g}$ of woodchips. Six bags of each woodchip type were placed at each location allowing the removal of one bag at each sampling time. To assess whether $P$. ramorum spores had contaminated the bagged woodchips and were viable, after each sampling time the contents of each bag was transferred to a plastic container in the laboratory, flooded with sterile water and five rhododendron leaf disks were placed floating on the water surface to bait for any viable $P$. ramorum associated with the woodchips as originally described by Tsao (1983). After 5 days, the leaf disks were removed and placed onto SMA plates, incubated at $20^{\circ} \mathrm{C}$ for 7 days, and the number of leaf disks with any outgrowth of $P$. ramorum recorded.

\section{Statistical analysis}

All experiments were designed with sufficient replication and balance to allow robust statistical analysis to be undertaken. A simple 1-way ANOVA which assumes a normally distributed error could not be adopted as a suitable model for analysis of the data recorded from this study.

This article is protected by copyright. All rights reserved. 
The microcosm experiments using woodchip and soil mixtures which generated cfu count data as an indicator of zoospore survival (summary data shown in Table 2) and the field trial which assessed the inhibitory activity of larch, rhododendron and pine woodchips exposed over a period of 52 weeks to natural inoculum of P. ramorum (see Table 7) were analysed by fitting a series of Generalised Linear Mixed Models (GLMM) (see Schall 1991). For the microcosm experiments, woodchip type (different host species: air-dried or heat-treated), isolates and incubation time were taken as fixed effects, and the number of trials and replicates as random effects. The Poisson error distributions were defined with a logit function for cfu count data. For the field trial, just as before the woodchip type, sampling time and sample location were taken as fixed effects; replicates were random effects. The Poisson error distributions were defined with a logit function for the proportion of $P$. ramorum positive baits.

For all other assays fitting a series of GLMM was severely compromised by the large number of zero or $100 \%$ values that were recorded across the various combinations of woodchip treatment, isolate and time in each dataset. To counteract this, exact statistics for binomial proportions were used to obtain confidence intervals (Brown et al. 2001) for each individual set of trials (ie for each combination of woodchip type and isolation) and these tested for differences between woodchip treatments, isolates and time. Thus, each assay trial was considered to have two possible outcomes (growth of $P$. ramorum or no growth) and each trial was considered statistically independent.

\section{Results}

\section{Microcosm experiments}

Heat-treated pine, larch and rhododendron woodchips completely inhibited the recovery of viable $P$. ramorum, regardless of isolate, compared to the air-dried woodchips $(p<0.001)$ (Table 1). All the inoculated air-dried wood treatments yielded colonies of $P$. ramorum after plating and the only notable difference was the slightly lower level of survival of P1578 zoospores compared to BRC01 which was found to be significant $(p<0.05)$. In contrast, neither isolate of $P$. ramorum was recovered from any of the heat-treated woodchips or from any of the water only amended controls.

This article is protected by copyright. All rights reserved. 
When similar numbers of zoospores were added to heat-treated larch woodchips mixed with nonsterile soil, there was no recovery of $P$. ramorum from the mixtures after 4 weeks of incubation even when the ground larch wood comprised only a quarter of the mix. After 8 weeks incubation, there was some recovery of P. ramorum from the same larch:soil mix (1:3), but the quantity was low (Table 2). More viable $P$. ramorum propagules (cfu) were always recovered from the soil only or soil-perlite mixtures compared with the larch-soil mixtures $(\mathrm{p}<0.001)$. Significantly more colonies were isolated from pure soil compared to the $1: 3$ ratio of perlite to soil mix, which itself produced significantly more colonies than the 3:1 perlite:soil mix $(p<0.001)$. Isolate BRC01 also yielded significantly more cfu than P1578 from the soil-woodchip mixtures $(p<0.001)$ (Table 2).

In further tests using leaf disks enriched with resilient $P$. ramorum chlamydospores placed in soillarch woodchip mixtures, the heat-treated larch woodchips completely inhibited the growth of $P$. ramorum (Table 3). Even when larch woodchips were mixed with soil (3 parts larch to 1 part soil) $P$. ramorum was recovered from $<6 \%$ of the leaf disks $(2.7 \%$ and $5.7 \%$ of the leaf disks for isolates P1578 and BRC01 respectively) after 4 weeks of incubation. With the same treatment, no growth of P. ramorum was recorded after 12 weeks incubation (Table 3). In contrast, between 86 and $100 \%$ of the infected leaf disks placed in either soil alone or a soil-perlite mixture yielded $P$. ramorum (Table 3). Overall, differences between treatments that contained heat-treated larch woodchips and those without larch woodchips were highly significant $(p<0.001)$ (Table 3). However, there were no significant differences between isolate or incubation time.

\section{Bioassays of crude wood extracts}

When the activity of methanol crude extracts made from woodchips of air-dried pine, larch and rhododendron was compared with extracts of heat-treated wood, strong differences were apparent (Table 4). None of the extracts from air-dried wood had an inhibitory effect on isolate BRC01 at any of the concentrations tested although isolate P1578 was inhibited by air-dried wood extracts from both pine and larch at a concentration of $25 \mathrm{mg} \mathrm{ml}^{-1}$. In contrast, the methanol crude extracts from heattreated pine, larch and rhododendron all inhibited $P$. ramorum growth $(p<0.001)$ and although there

This article is protected by copyright. All rights reserved. 
were slight differences depending on the isolate and wood species these were not statistically significant. The lowest minimum inhibitory concentration (MIC) when using extracts from heattreated pine and larch was $6.25 \mathrm{mg} \mathrm{ml}^{-1}$ against isolate P1578, and $12.5 \mathrm{mg} \mathrm{ml}^{-1}$ and $6.25 \mathrm{mg} \mathrm{ml}^{-1}$ against isolate BRC01 (pine and larch respectively). Methanol extracts derived from heat-treated rhododendron wood had a MIC of $25 \mathrm{mg} \mathrm{ml}^{-1}$ against P1578 and $50 \mathrm{mg} \mathrm{ml}^{-1}$ against BRC01 (Table 4).

Methanol crude extracts of heat-treated larch, pine and rhododendron at a concentration of $10 \mathrm{mg} \mathrm{ml}^{-1}$ also significantly reduced the outgrowth of $P$. ramorum from chlamydospore-rich leaf disks by more than $90 \%$ compared to similar extracts from air-dried wood $(p<0.001$, calculated at $95 \%$ confidence limits). Overall, the mean number of leaf disks yielding P. ramorum was much higher $(>80 \%)$ when the crude extract was derived from air-dried wood, regardless of whether it came from pine, larch or rhododendron, compared to the mean number of leaf disks $(<20 \%)$ yielding $P$. ramorum when the crude extract came from heat-treated woodchips (Fig 1).

\section{Compound assessments and chemical analyses}

Initial tests concentrated on using heat-treated pine wood crude extract and the pure wood-derived compounds acetovanillone, coniferaldehyde and vanillin which had already been shown to have antimicrobial activity against bacterial pathogens (Kalantarzadeh 2014). These compounds had activities 2-10 times greater than the crude extract when tested against zoospores, chlamydospores and mycelia of $P$. ramorum (Table 5). Coniferaldehyde proved the most inhibitory (MIC of 0.15 mmolar against zoospores; 1.7 mmolar against mycelium and chlamydospores) whilst acetovanillone and vanillin had similar antimicrobial properties (MICs of 1.5-1.6 mmolar against zoospores, 3.4-6.6 mmolar against mycelia and chlamydospores). All compounds (including the crude extract) had similar activities against the two $P$. ramorum isolates used in the assays.

This article is protected by copyright. All rights reserved. 
Addition of $20 \mathrm{mmol}$ of the resin acid dehydroabietic acid to coniferaldehyde and acetovanillone reduced the MIC 8-fold, whilst in combination with vanillin the MIC was reduced 4-fold. The effects were similar with both isolates of $P$. ramorum (Table 6). Likewise, in a subsequent assay which combined acetovanillone, coniferaldehyde and vanillin with either dehydroabietic acid or abietic acid, the MIC decreased 4 to 16-fold. However, the addition of another resin acid, pimaric acid, had no significant effect on the MIC (Table 6).

GCMS analysis of the methanol crude extracts of heat-treated pine, larch and rhododendron $\left(1 \mathrm{mg} \mathrm{ml}^{-1}\right.$ methanol) revealed a number of chemical constitutents (Fig 2, a-c). Spectra of all three crude extracts had peaks for vanillin at 13.7 minutes, vanillic acid at 15.8 minutes, and syringaldehyde at 16.9 minutes. The peak for vanillin was considerably higher in the crude extract of pine and larch compared to rhododendron. One peak at 17.7 minutes, identified as coniferaldehyde (NIST library), was only present in larch and pine extracts. In contrast, benzoic acid (18.67 minutes), syringic acid (18.73 minutes) and sinapaldehyde (20.34 minutes) were only present in the crude extract of rhododendron (Fig 2, c).

Analysis of dichloromethane $\left(\mathrm{CH}_{2} \mathrm{Cl}_{2}\right)$ crude extracts of naturally infected Japanese larch bark revealed that prior to detection of the pathogen in invaded bark, the white phloem tissue at the edge of the lesion (i.e. apparently uninvaded tissue) showed an abundance of resin acid 2 (24.8 minutes) and much lower amounts of resin acid 1 (24 minutes) compared with the similarly coloured phloem tissue from an uninfected tree (control) (Fig 3 a, b). However, in the crude extract of the red-discoloured bark, resin acids 1 and 2 were present in considerable quantities, but in the brown tissue, where recovery of $P$. ramorum was usually the easiest, resin acid 2 was at levels similar to the control (Fig 3 c, d). Due to the trace quantity of resin acids, they could only be identified from a chromatogram of a spiked sample of $\mathrm{CH}_{2} \mathrm{Cl}_{2}$ crude extract with $10 \mathrm{mg}$ of synthetic dehydroabietic acid and abietic acid. Resin acid 2 was identified as dehydroabietic acid (Fig 3 a) and resin acid 1 was identified as methyl abietate (Fig. 3 b), a derivative of abietic acid. The red discoloured tissue had raised levels of many other compounds compared with the control and white coloured phloem tissue. Monoterpenes, $\alpha-$

This article is protected by copyright. All rights reserved. 
pinene (6.14 minutes) and 3-carene (7.58 minutes) were only present in the extracts of red and dark brown phloem tissue and were apparently formed as a host response during pathogen invasion (Fig 3 c, d).

\section{Field tests}

No viable $P$. ramorum was detected from either the air-dried or heat-treated wood chips of pine, larch or rhododendron after 4, 8 and 12 weeks field exposure on the trial site in Cornwall (Table 7) but monitoring of infected plants on site during that twelve-week period indicated very little $P$. ramorum inoculum was produced between November to February. After 20 weeks, P. ramorum was isolated from the air-dried rhododendron woodchips, demonstrating that natural inoculum was being generated from infected host plants and coming into contact with the woodchips. Despite this, P. ramorum was not isolated from either the pine or larch woodchips although the difference in the amount of $P$.

ramorum recovery between the three treatments was not statistically significant. However, after 52 weeks on the site (up to November 2012), there was more than a 2-fold increase in the recovery of $P$. ramorum from the air-dried larch and pine wood chips compared to the heat-treated wood chips $(p<0.001)$. In contrast, although recovery from the heat-treated rhododendron woodchips was slightly lower than the air-dried material, levels of $P$. ramorum were not significantly different between the two (Table 7).

\section{Discussion}

Heat-treating chipped wood from rhododendron, pine and larch at $120^{\circ} \mathrm{C}$ for 72 hours enhanced the anti-microbial activity when compared to similar woodchips that had only been air-dried and not exposed to elevated temperatures. In particular, the wood from pine and larch appeared to become strongly inhibitory to spores and mycelium of $P$. ramorum after heat treatment and significantly reduced the recovery of the pathogen. Rhododendron woodchips, in contrast, never caused the same degree of inhibition. Furthermore, when heat-treated larch was mixed with soil in varying proportions and then exposed to zoospores and chlamydospores in the laboratory, the inhibitory effect continued

This article is protected by copyright. All rights reserved. 
for up to 12 weeks although the two isolates of EU1 lineage $P$. ramorum used in the tests showed small but significant differences in sensitivity.

Earlier work by Manter and co-workers $(2006,2007)$ which evaluated the antimicrobial activity of yellow cedar against $P$. ramorum, demonstrated a correlation between bioassay results from the chemical components and the effectiveness of woodchips used in field treatments. Likewise, our study showed that both in the field and under controlled laboratory conditions heat-treated woodchips of larch and pine were strongly inhibitory to the pathogen. In the field trial the inhibitory effect of heattreated pine and larch woodchips was evident for up to a year. Activity was also retained in soil/woodchip mixtures under moist conditions even though high moisture has been shown to favour survival and recovery of P. ramorum from infested soils and leaf litter (Fichtner et al. 2007).

Our bioassay tests showed the responses of the two P. ramorum isolates to crude extracts of heattreated were dose dependent and the extracts appeared to contain a range of compounds, some of which were highly inhibitory. When pure compounds vanillin, acetovanillin and confieraldehyde were tested they were found to be 2-10 times more active than the crude extracts. Since all three tested wood species showed some inhibitory activity, the potential inhibitors are likely to be produced through heat mediated chemical modifications of the wood. Chemical analysis of the methanol extracts showed some of the induced compounds were present in all three wood extracts but those with the most activity against $P$. ramorum were either absent or only present at lower concentrations in rhododendron wood as compared to larch or pine. With gas chromatography mass spectrometry analysis, the peak for vanillin, a phenolic aldehyde, was considerably higher in the extracts of pine and larch than in the rhododendron extract. In addition, coniferaldehyde which was only present in larch and pine extracts, proved to be the most active compound in limiting growth of mycelium, chlamydospores and zoospores of $P$. ramorum. The absence of coniferaldehyde in the crude extract of heat-treated rhododendron appears to be the reason why pine and larch extracts had a much greater inhibitory effect on $P$. ramorum than heat-treated rhododendron woodchips. A previous study by

This article is protected by copyright. All rights reserved. 
Garbber et al. (1998) found that cell wall degradation of maize by fungal enzymes was severely limited by the presence of coniferaldehyde, highlighting the antimicrobial activity of this compound.

The results of chemical analysis and the bioassays of identified compounds in our study also suggest that the magnitude of antimicrobial activity may not just be due to some individual compounds, such as aldehydes and phenolic aldehydes, but result from the synergistic activity between some of the compounds. Dehydroabietic and abietic acid are diterpenoid components of heat-treated pine and larch and both these resin acids enhanced the inhibitory effect of aldehydes such as coniferaldehyde and vanillin. The same resin acids are known to be present in oleoresin produced by conifers (Savluchinske-Feio et al. 1999) and have low toxicity toward fungal pathogens but are of importance in sealing wounds and trapping insect invaders (Bollschweiler et al. 2007; Cleary 2010). In addition, higher concentrations of resin acids in decay resistant species are associated with the resistance of heartwood to brown-rot fungi, with abietic acid being the most abundant.

Interestingly, chemical analysis of the red discoloured region of Japanese larch bark in the process of being invaded by $P$. ramorum, not only revealed some of the same compounds found in the heattreated larch wood but also provided evidence of resin acid production induced by $P$. ramorum. The increased resin acid content of infected phloem tissue suggests these compounds could play an important role in inhibiting the growth of $P$. ramorum as it attacks larch bark, but the effectiveness of the inhibition may depend on concentrations in the bark and potentially be overcome by the multiple infections that occur under natural conditions (Webber and Brasier 2018). The pattern of chemical changes observed in the phloem tissue of infected larch prior to, during and post invasion, also showed raised levels of many other compounds in addition to the resin acids. In particular, peaks for $\alpha$-pinene and 3-carene in the extracts of red and dark brown phloem tissue were markedly higher. Both are found in the essential oils of conifers that exhibit toxic activity against many fungi and insects (Napierała Filipiak et al. 2002; Phillips and Croteau 1999).

This article is protected by copyright. All rights reserved. 
Phenolics such as ellagic acid and a tyrosol derivative have already been found in the phloem of Quercus agrifolia Née (coast live oak), another species frequently infected by $P$. ramorum in the mixed-evergreen forests of California. Surviving coast live oaks appear to have constitutively higher levels of these phenolics than more $P$. ramorum susceptible individuals suggesting the compounds would be good candidates for examination as potential biomarkers for resistance to $P$. ramorum (Nagle et al. 2011; Conrad et al. 2014). For the same reasons, a greater understanding of what compounds are induced in Japanese larch bark during the early stages of pathogen attack could provide insights into what resistance mechanisms against $P$. ramorum are already operating. They could also be important traits to select for in any larch breeding programme aimed at finding genetic resistance to P. ramorum. Additionally, the active antimicrobial chemicals found in the heat-treated larch and pine wood could be novel candidates in the development of chemical treatments against $P$. ramorum and possibly other pathogens.

\section{Conclusions}

Extensive research efforts aimed at finding effective methods to eliminate or control P. ramorum have included chemical control to counter host infection (e.g. Garbelotto and Schmidt 2009), composting of infected residues (e.g. Swain et al. 2006) and searching for resistance (e.g. Conrad et al. 2014). Many of these disease-focussed studies have been summarised by Kliejunas (2010) but he also concluded that no single strategy is likely to be effective in eradicating $P$. ramorum, especially once it has established in the wider environment. The use of woodchips with enhanced antimicrobial activity against $P$. ramorum could offer another tool for reducing pathogen survival in wider environment outbreaks.

When taking action against $P$. ramorum infestations in natural and semi-natural environments, best management practices tend to concentrate on slowing disease spread as eradication efforts are difficult to implement successfully in these complex environments compared with the relatively controlled setting of nurseries. Safe disposal or containment of infested material from the wider environment outbreaks is also frequently challenging and costly. Spores, including persistent chlamydospores of $P$.

This article is protected by copyright. All rights reserved. 
ramorum readily survive in soil and fallen foliage (Fichtner et al. 2007) and this inoculum reservoir is implicated in the infection of susceptible hosts such as rhododendron as it re-sprouts or reinvades following the clearance of infected hosts (Elliot et al. 2013; Harris 2015). Thus using a layer of woodchips to act as a barrier between infested soil/litter and the shrub or brush layer above could potentially prevent reinfection and inoculum multiplication.

Although our data indicated that the inhibitory activity of larch and pine woodchips generated after heat-treatment has the potential to operate in ecologically complex environments over several weeks and even for up to a year, the effect is likely to be modulated by external influences. Rainfall will probably leach the antimicrobials from the woodchips over time whilst soil microbes may break down the compounds in situ. Consequently, if woodchip treatments are to be used for long-term suppression of $P$. ramorum in natural environments further investigation and trialling is recommended, as the tests have only focussed on the EU1 lineage of the pathogen. For deployment, the method might be most useful in parks and gardens to treat limited areas following removal of infected plants to suppress any remaining inoculum and prevent reinfection of nearby susceptible hosts. Goheen (2013) also highlights the use of woodchip treatments for places where human activities likely to disperse $P$. ramorum are concentrated, such as roads, walk-ways and paths in infested forests and woodlands. However, there would be extra cost implications if woodchips are used that have to be heat-treated.

\section{Acknowledgements}

Funding for this project on Phytophthora ramorum was provided by the Defra Funded Project CTX0907 and all laboratory work was conducted under quarantine licence FCPHS 2/2015. We thank Principal Statistician Andrew Peace for advising on statistical analyses, and Dr. Gavin Hunter, Mr. Tony Hutchings and Mr Tony Reeves (Forest Research) and Dr. Moses Langat (University of Surrey) for their assistance and helpful advice. We also thank two anonymous reviewers for their careful reading of the manuscript and many thoughtful comments and suggestions to improve it. We

This article is protected by copyright. All rights reserved. 
acknowledge Forest Research (Farnham, Surrey) and University of Surrey (Guildford) for providing the facilities needed to conduct this study.

\section{References}

Bollschweiler M, Stoffel M, Schneuwly DM, Bourqui K (2007) Traumatic resin ducts in Larix decidua stems impacted by debris flows. Tree Physiol 28: 255-263

Brasier CM, Denman S., Rose J, Kirk SA, Lane C, Hughes K, Griffin R, Inman A, Webber JF. (2004a) First report of ramorum bleeding canker on Quercus falcata, caused by Phytophthora ramorum. Plant Pathol 53:804-804. http//doi: 10.1111/j.1365-3059.2004.01079.x

Brasier C, Denman S, Brown A, Webber J (2004b) Sudden oak death (Phytophthora ramorum) discovered on trees in Europe. Mycol Res 108: 1108-1110

Brasier CM, Kirk SA (2002) Comparative aggressiveness of standard and variant hybrid alder Phytophthoras, Phytophthora cambivora and other Phytophthora species on bark of Alnus, Quercus and other woody hosts. Plant Pathol 50:219-229

Brasier CM, Webber J (2010) Sudden Larch Death. Nature 466:824-825

Brown L D, Cai TT, DasGupta A (2001) Interval estimation for a binomial proportion. Statist. Sci. 16(2): 101--133. http//doi:10.1214/ss/1009213286

Cleary MR (2010) Traumatic resin duct formation in the phloem of western red cedar and other resistance mechanisms effective against Armillaria root disease In: The International Symposium - A Tale of Two Cedars: Western redcedar and yellow-cedar University of Victoria, Victoria British Columbia. Forest Service Pacific Northwest Research Station, pp 53-56

Conrad AO, Rodriguez-Saona LE, McPherson BA, Wood DL, Bonello P (2014) Identification of Quercus agrifolia (coast live oak) resistant to the invasive pathogen Phytophthora ramorum in native stands using Fourier-transform infrared (FT-IR) spectroscopy. Front. Plant Sci. 5:521. doi: 10.3389/fpls.2014.00521

Cushman JH, Cooper M, Meentemeyer RK, Benson S (2008) Human activity and the spread of Phytophthora ramorum. In: Frankel SJ, Kliejunas JT, Palmieri KM (ed) The sudden oak death third science symposium, Albany, CA: U.S., 2008. Department of Agriculture, Forest Service, Pacific Southwest Research Station, pp 179-180

This article is protected by copyright. All rights reserved. 
Defra (2008) Phytophthora ramorum. A Practical Guide for Established Parks \& Gardens, Amenity Landscape and Woodland Areas. Department for Environment, Food and Rural Affairs. www.fera.defra.gov.uk/plants/publications/documents/.../pramparks.pdf

Denman S, Kirk SA, Brasier CM, Webber JF (2005) In vitro leaf inoculation studies as an indication of tree foliage susceptibility to Phytophthora ramorum in the UK. Plant Pathol 54:512-521. http//doi.10.1111/j.1365-3059.2005.01243.x

Elliot M, Meagher TR, Harris C, Searle K, Purse BV, Schlenzig A (2013) The epidemiology of Phytophthora ramorum and P. kernoviae at two historic gardens in Scotland. In Proceedings of the Sudden Oak Death Fifth Science Symposium; Frankel SJ, Kliejunas JT, Palmieri KM, Alexander JM (tech. coords.). Tech. Rep. PSW-GTR-243. Albany, CA: Pacific Southwest Research Station, Forest Service, U.S. Department of Agriculture, pp 23-32

Esteves B, Marques AV, Domingos I, Pereira H (2008) Heat-induced colour changes of pine (Pinus pinaster) and eucalypt (Eucalyptus globulus) wood. Wood Sci Technol 42:369-384. http//doi. 10.1007/s00226-007-0157-2

Fichtner EJ, Lynch SC, Rizzo DM (2007) Detection, distribution, sporulation, and survival of Phytophthora ramorum in a California redwood-tanoak forest soil. Phytopathology 97:1366-1375. http//doi.10.1094/Phyto-97-10-1366

Frankel SJ (2008). Sudden oak death and Phytophthora ramorum in the USA: a management challenge. Australas Plant Path 37:19-25

Garbber JH, Ralph J, Hatfield RD (1998) Severe inhibition of maize wall degradation by synthetic lignins formed with coniferaldehyde. J Sci Food Agr 78:81-87. http//doi.10.1002/(Sici)10970010(199809)78:1<81::Aid-Jsfa86>3.3.Co;2-E

Garbelotto M, Schmidt DJ (2009) Phosphonate controls sudden oak death pathogen for up to 2 years. California Agr 66: 10-17

Goheen EM. (2013) Reducing the spread of Phytophthora ramorum on the Redwood Nature Trail, Rogue River-Siskiyou National Forest, Curry County, Oregon: A Case Study. In: Proceedings of the sudden oak death fifth science symposium; Frankel SJ; Kliejunas JT, Palmieri KM; Alexander JM, (tech. cords). Gen. Tech. Rep. PSW-GTR-243. Albany, CA: U.S. Department of Agriculture, Forest Service, Pacific Southwest Research Station: p. 141

Grunwald NJ, Garbelotto M, Goss EM, Heungens K, Prospero S (2012) Emergence of the sudden oak death pathogen Phytophthora ramorum. Trends Microbiol 20:131-138. http//doi.10.1016/j.tim.2011.12.006

This article is protected by copyright. All rights reserved. 
Harris AR (2015) The epidemiology of Phytophthora ramorum associated with Larix in the UK. Imperial College: London, UK. https://spiral.imperial.ac.uk/handle/10044/1/24862

Harris AR, Webber JF (2016) Sporulation potential, symptom expression and detection of Phytophthora ramorum on larch needles and other foliar hosts. Plant Pathol 65: 1441-1451. https://doi.org/10.1111/ppa.12538

Harris AR, Mullett M, Webber JF (2018) Changes in the population structure and sporulation behaviour of Phytophthora ramorum associated with the epidemic on Larix (larch) in Britain. Biol. Invasions http://link.springer.com/content/pdf/10.1007\%2Fs10530-018-1702-7.pdf

Kalantarzadeh M (2014) Development of a heat treatment to enhance the antimicrobial properties of wood based mulches and animal bedding materials. PhD Thesis, University of Surrey

Kamdem DP, Pizzi A, Jermannaud A (2002) Durability of heat-treated wood. Holz Roh Werkst 60:16. https//doi.10.1007/s00107-001-0261-1

Kliejunas JT (2010) Sudden oak death and Phytophthora ramorum: a summary of the literature. 2010 edition. Gen. Tech. Rep. PSW-GTR-234. Albany, CA: U.S. Department of Agriculture, Forest Service, Pacific Southwest Research Station. 181 p. https://doi.org/10.2737/PSW-GTR-234

Manter DK, Karchesy JJ, Kelsey RG (2006) The sporicidal activity of yellow-cedar heartwood, essential oil and wood constituents towards Phytophthora ramorum in culture. Forest Pathol 36:297308. https//doi.10.1111/j.1439-0329.2006.00461.x

Manter DK, Kelsey RG, Karchesy JJ (2007) Antimicrobial activity of extractable conifer heartwood compounds toward Phytophthora ramorum. J Chem Ecol 33:2133-2147. https//doi.10.1007/s10886007-9368-0

Napierała Filipiak A, Werner A, Mardarowicz M, Gawdzik J (2002) Concentrations of terpenes in mycorrhizal roots of Scots pine (Pinus sylvestris) seedlings grown in vitro. J Plant Physiol 24:137-143

Nagle AM, McPherson BA, Wood DL, Garbelotto M, Bonello P (2011) Relationship between field resistance to Phytophthora ramorum and constitutive phenolic chemistry of coast live oak. Forest Pathol 41:464-469. https//doi.10.1111/j.1439-0329.2010.00703.x.

O'Hanlon R, Choiseul J, Brennan JM, Grogan H (2017) Assessment of the eradication measures applied to Phytophthora ramorum in Irish Larix kaempferi forests. Forest Pathol https://doi.org/10.1111/efp.12389

Phillips MA, Croteau RB (1999) Resin-based defences in conifers. Trends Plant Sci 4:184-190

This article is protected by copyright. All rights reserved. 
Rizzo DM, Garbelotto M, Davidson JM, Slaughter GW, Koike ST (2002) Phytophthora ramorum as the cause of extensive mortality of Quercus spp. and Lithocarpus densiflorus in California. Plant Dis $86: 205-214$

Sansford CE, Inman AJ, Baker R, Brasier C, Frankel S, de Gruyter J, Husson C, Kehlenbeck H, Kessel G, Moralejo E, Steeghs M, Webber J, Werres S (2009) Report on the risk of entry, establishment, spread and socio-economic loss and environmental impact and the appropriate level of management for Phytophthora ramorum for the EU. Deliverable Report 28, EU Project Risk Analysis of Phytophthora ramorum, a Newly Recognised Pathogen Threat to Europe and the Cause of Sudden Oak Death in the USA (Acronym - RAPRA). https://hal.archives-ouvertes.fr/hal-01245979/document

Savluchinske-Feio SS, Gigante B, Roseiro JC, Marcelo-Curto MJ (1999) Antimicrobial activity of diterpene resin acid derivatives. J Microbiol Meth 35:201-206

Schall R (1991) Estimation in generalized linear models with random effects. Biometrika 78(4):719727. https//doi.org/10.1093/biomet/78.4.719

Swain S, Harnik T, Mejia-Chang M, Hayden K, Bakx, W, Creque J, Garbelotto M (2006) Composting is an effective treatment option for sanitization of Phytophthora ramorum-infected plant material. $\mathrm{J}$ Appl Microbiol 92:1143-1158. https://doi.org/10.1111/j.1365-2672.2006.03008.x

Sundqvist B (2004) Colour changes and acid formation in wood during heating. PhD, Lulea University of Technology

Tooley PW, Browning M (2008). Survival of Phytophthora ramorum chlamydospores at high and low temperatures. In: Proceedings of the Sudden Oak Death third science symposium; Frankel SJ; Kliejunas JT; Palmieri KM (tech. coord). Gen. Tech. Rep. PSW-GTR-214. Albany, CA: U.S. Department of Agriculture, Forest Service, Pacific Southwest Research Station. p. 475

Tracy DR (2009) Phytophthora ramorum and Phytophthora kernoviae: the woodland perspective. EPPO Bull 39:161-167

Tsao PH (1983) Factors affecting the isolation and quantification of Phytophthora from soil. In: Phytophthora, its Biology, Taxonomy, Ecology, and Pathology (Erwin DC, Bartnicki-Garcia S, Tsao PH, eds), pp 219-236. St Paul, MN, USA: APS.

Turner J, Jennings P, Humphries G (2005) Phytophthora ramorum epidemiology: sporulation potential, dispersal, infection, latency and survival. Department for Environment, Food and Rural Affairs (DEFRA) Project Report PH0194, http://randd.defra.gov.uk/Document.aspx.

This article is protected by copyright. All rights reserved. 
Webber JF Brasier CM (2018) Ramorum Disease of Larch. In: Hansen EM, Lewis KJ, Chastagner GA (eds) Compendium of Conifer Diseases (second edition). St. Paul, MN, USA: APS Press.

Webber JF, Mullett M, Brasier CM (2010 ) Dieback and mortality of plantation Japanese larch (Larix kaempferi) associated with infection by Phytophthora ramorum New Disease Reports 22 https//doi.10.5197/j.2044-0588.2010.022.019

Webber JF, Rose J (2008) Dissemination of aerial and root infecting Phytophthoras by human vectors. In: The Sudden Oak Death third science symposium, Frankel SJ, Kliejunas JT, Palmieri KM (ed). Albany, CA: U.S., 2008. Department of Agriculture, Forest Service, Pacific Southwest Research Station, pp 195-198

Werres S, Marwitz R, Man in't Veld WA, De Cock AWAM, Bonants PJM, De Weerdt M, Themann K, Ilieva E, Baayen RP (2001) Phytophthora ramorum sp. nov., a new pathogen on Rhododendron and Viburnum. Mycol Res 105:1155-1165 https//doi: 10.1016/S0953-7562(08)61986

This article is protected by copyright. All rights reserved. 


\section{Figure legends}

Figure 1 Effect of methanol crude extracts of air-dried (AD) and heat-treated (H) wood of pine, larch and rhododendron on the outgrowth of Phytophthora ramorum from pre-colonised chlamydospores-rich leaf disks of rhododendron after plating onto selective medium. The mean number of disks with $P$. ramorum growth was calculated as a percentage from two trials, each with a total of 12 disks for each treatment.

Figure 2 Comparison of gas chromatography spectra of methanol crude extracts of (a) heated pine (b) larch and (c) rhododendron. Peak 1 is vanillin, 2 is vanillic acid, 3 is syringaldehyde, 4 is coniferaldehyde, 5 is benzoic acid, 6 is syringic acid, and 7 sinapaldehyde.

Figure 3 Comparison of gas chromatography spectra of crude $\mathrm{CH}_{2} \mathrm{CL}_{2}$ extracts from Japanese larch bark. (a) phloem tissue of a healthy tree, (b) white phloem prior to invasion (c) red discoloration following invasion and (d) dark brown phloem formed as a response to invasion by $P$. ramorum. Peaks 1 and 2 represent two resin acids at 24.00 minutes and 24.7 minutes respectively.

This article is protected by copyright. All rights reserved. 
Table 1 Recovery of Phytophthora ramorum three weeks after inoculation of air-dried and heattreated woodchips of pine, larch and rhododendron. Woodchips were incubated with zoospore inoculum for three weeks and then placed onto selective medium to assess the growth of $P$. ramorum from surviving inoculum. $P$ levels expressed for a $95 \%$ confidence limit

\begin{tabular}{|c|c|c|c|c|c|}
\hline \multirow[b]{2}{*}{ Treatment } & \multirow[b]{2}{*}{$\begin{array}{l}\text { No of } \\
\text { trials }\end{array}$} & \multirow[b]{2}{*}{$\mathbf{n}$} & \multicolumn{2}{|c|}{$\begin{array}{l}\text { Recovery of } P \text {. } \\
\text { ramorum from } \\
\text { inoculated woodchips }\end{array}$} & \multirow{2}{*}{$\begin{array}{l}\text { Significance for } \\
\text { isolate BRC01 vs } \\
\text { P1578 across all } \\
\text { woodchip types }\end{array}$} \\
\hline & & & $\begin{array}{l}\text { Isolate } \\
\text { BRC01 }\end{array}$ & $\begin{array}{l}\text { Isolate } \\
\text { P1578 }\end{array}$ & \\
\hline \multicolumn{6}{|l|}{ Air-dried woodchips } \\
\hline Scots pine (Pinus sylvestris) & 4 & 10 & $10.0^{*}$ & $9.0 *$ & \\
\hline Japanese larch (Larix kaempferi) & 4 & 10 & 9.8 & 8.1 & \\
\hline Rhododendron (Rhododendron ponticum) & 4 & 10 & 10.0 & 10.0 & $p<0.05$ \\
\hline \multicolumn{6}{|l|}{ Heat-treated woodchips } \\
\hline Scots pine ( $P$. sylvestris) & 4 & 10 & 0.0 & 0.0 & \\
\hline Japanese larch (L. kaempferi) & 4 & 10 & 0.0 & 0.0 & \\
\hline Rhododendron (R. ponticum) & 4 & 10 & 0.0 & 0.0 & \\
\hline Significance for air-dried vs heat-treated & & & $p<0.001$ & $p<0.001$ & \\
\hline
\end{tabular}

* Means calculated from four trials and 10 replicates for each treatment within a trial. Except for the larch woodchips $P$. ramorum was recovered from all replicates/trials of air dried woodchips and none of the heat-treated woodchips.

This article is protected by copyright. All rights reserved. 
Table 2 Effect of diluting heat-treated larch (Larix kaempferi) woodchips with non-sterile soil on the survival of two isolates of Phytophthora ramorum, 4 and 8 weeks after inoculation with zoospores. Successful recovery of viable $P$. ramorum was demonstrated by the number of colony forming units (cfu) produced after plating a gram of the mixture onto Phytophthora selective medium.

\begin{tabular}{|c|c|c|c|c|c|c|}
\hline \multirow{3}{*}{ Treatment } & \multirow{3}{*}{$\mathbf{n}$} & \multicolumn{4}{|c|}{ Mean zoospore recovery $\pm \mathrm{SE}\left(\mathrm{cfu}^{-1}\right)$} & \multirow{3}{*}{ p value } \\
\hline & & \multicolumn{2}{|c|}{ Isolate BRC01 } & \multicolumn{2}{|c|}{ Isolate P1578 } & \\
\hline & & 4 weeks & 8 weeks & 4 weeks & 8 weeks & \\
\hline All larch & 4 & 0.0 & 0.0 & 0.0 & 0.0 & \\
\hline 3 parts larch : 1 part soil & 4 & 0.0 & 0.0 & 0.0 & 0.0 & \\
\hline 1 part larch : 3 parts soil & 4 & 0.0 & $0.6 \pm 0.1$ & 0.0 & $0.5 \pm 0.1$ & \\
\hline 3 parts perlite : 1 part soil & 4 & $3.8 \pm 0.7$ & $1.0 \pm 0.0$ & $2.1 \pm 0.3$ & $1.2 \pm 0.1$ & \\
\hline 1 part perlite $: 3$ parts soil & 4 & $5.6 \pm 0.8$ & $2.1 \pm 0.2$ & $4.4 \pm 0.5$ & $2.0 \pm 0.0$ & \\
\hline All soil & 4 & $6.7 \pm 0.2$ & $4.2 \pm 0.4$ & $5.0 \pm 0.2$ & $3.5 \pm 0.6$ & \\
\hline \multicolumn{6}{|c|}{ Significance for larch + soil mixtures vs perlite + soil mixtures } & $p<0.001$ \\
\hline \multicolumn{6}{|c|}{ Significance for 4 week vs 8 week incubation (only for 1:3 larch:soil mixture) } & $p<0.01$ \\
\hline \multicolumn{6}{|c|}{ Significance for isolate BRC01 vs isolate $\mathrm{P1578}$ across all mixtures } & $p<0.001$ \\
\hline
\end{tabular}

This article is protected by copyright. All rights reserved. 
Table 3 Effect of diluting heat-treated larch (Larix kaempferi) woodchips with non-sterile soil on the germination of Phytophthora ramorum chlamydospores present in rhododendron leaf disks after 4 and 12 weeks of incubation. Successful recovery of viable $P$. ramorum was demonstrated by outgrowth from the leaf disks plated onto Phytophthora selective medium. $P$ levels expressed for a $95 \%$ confidence limit.

\begin{tabular}{|c|c|c|c|c|c|c|c|}
\hline \multirow{3}{*}{ Treatment } & \multirow{3}{*}{$\begin{array}{l}\text { No. of } \\
\text { trials } \\
\text { (pots) }\end{array}$} & \multirow{3}{*}{$\mathbf{n}$} & \multicolumn{4}{|c|}{ \% leaf disks with $P$. ramorum outgrowth } & \multirow[b]{3}{*}{$p$ value } \\
\hline & & & \multicolumn{2}{|c|}{ Isolate BRC01 } & \multicolumn{2}{|c|}{ Isolate P1578 } & \\
\hline & & & 4 weeks & 12 weeks & 4 weeks & 12 weeks & \\
\hline All larch & 3 & 12 & $0.0 \% *$ & $0.0 \% *$ & $0.0 \% *$ & $0.0 \% *$ & \\
\hline 3 parts larch : 1 part soil & 3 & 12 & $5.5 \%$ & 0.0 & $2.7 \%$ & 0.0 & \\
\hline 3 parts perlite : 1 part soil & 3 & 12 & $86.1 \%$ & $91.7 \%$ & $91.7 \%$ & $94.5 \%$ & \\
\hline All soil & 3 & 12 & $100 \%$ & $100 \%$ & $100 \%$ & $100 \%$ & \\
\hline \multicolumn{7}{|c|}{ Significance for larch + soil mixtures vs perlite + soil mixtures } & $p<0.001$ \\
\hline \multicolumn{7}{|c|}{ Significance for 4 weeks vs 12 weeks and isolate BRC01 vs isolate P1578 } & $p>0.1$ \\
\hline
\end{tabular}

*Means calculated from three trials, with 12 leaf disks per trial

This article is protected by copyright. All rights reserved. 
Table 4 Minimum inhibitory concentration (MIC) of the methanol crude extract ( $\mathrm{mg} \mathrm{ml}^{-1}$ ) obtained from air-dried and heat-treated wood of pine, larch and rhododendron and tested against zoospores of Phytophthora ramorum derived from two isolates (BRC01 and P1578).

\begin{tabular}{|c|c|c|c|c|c|c|}
\hline \multirow[t]{3}{*}{ Crude wood extract } & \multirow[t]{3}{*}{$\mathbf{n}$} & \multicolumn{4}{|c|}{$\begin{array}{l}\text { Minimum inhibitory concentration (mg } \\
\mathrm{ml}^{-1} \text { ) }\end{array}$} & \multirow{3}{*}{$\begin{array}{l}p \\
\text { value }\end{array}$} \\
\hline & & \multicolumn{2}{|c|}{ Heat-treated wood } & \multicolumn{2}{|c|}{ Air-dried wood } & \\
\hline & & BRC01 & P1578 & BRC01 & P1578 & \\
\hline Scots pine (Pinus sylvestris) & 3 & $\geq 12.5$ & $\geq 6.25$ & 0.0 & $\geq 25$ & \\
\hline Japanese larch (Larix kaempferi) & 3 & $\geq 6.25$ & $\geq 6.25$ & 0.0 & $\geq 25$ & \\
\hline Rhododendron (Rhododendron ponticum) & 3 & $\geq 50$ & $\geq 25$ & 0.0 & 0.0 & \\
\hline $\begin{array}{l}\text { Significance for air-dried vs heat- } \\
\text { treated }\end{array}$ & & & & & & $p<0.01$ \\
\hline $\begin{array}{l}\text { Significance between isolates and } \\
\text { between wood species }\end{array}$ & & & & & & $p>0.1$ \\
\hline
\end{tabular}

* MIC was the same for each replicate

This article is protected by copyright. All rights reserved. 
Table 5 Minimum inhibitory concentration (MIC) of the compounds derived from heat-treated wood of Scots pine (Pinus sylvestris) tested against mycelia, zoospores and chlamydospores derived from two isolates of Phytophthora ramorum (BRC01 and P1578).

\begin{tabular}{|c|c|c|c|c|c|c|c|}
\hline \multirow{3}{*}{ Compounds } & \multirow{3}{*}{$\mathbf{n}$} & \multicolumn{6}{|c|}{ Minimum inhibitory concentration (mmolar) } \\
\hline & & \multicolumn{2}{|l|}{ Mycelia } & \multicolumn{2}{|c|}{ Zoospores } & \multicolumn{2}{|c|}{ Chlamydospores } \\
\hline & & BRC01 & P1578 & BRC01 & P1578 & BRC01 & $\mathbf{P 1 5 7 8}$ \\
\hline Crude pine wood extract* & 3 & 25 & 25 & 12.5 & 6.25 & 10 & 10 \\
\hline Acetovanillone & 3 & 6.6 & 3.3 & 1.6 & 1.6 & 6.6 & 3.3 \\
\hline Coniferaldehyde & 3 & 1.7 & 1.7 & 0.15 & 0.15 & 1.7 & 1.7 \\
\hline Vanillin & 3 & 3.4 & 3.4 & 1.52 & 1.52 & 3.4 & 3.4 \\
\hline
\end{tabular}

* MIC for crude extract expressed as $\mathrm{mg} \mathrm{ml}^{-1}$

This article is protected by copyright. All rights reserved. 
Table 6 Minimum inhibitory concentration (MIC) of acetovanillone, coniferaldehyde and vanillin, with and without $20 \mathrm{mmol}$ dehydroabietic acid (DHAA), $20 \mathrm{mmol}$ abietic acid and $20 \mathrm{mmol}$ pimaric acid, tested against zoospores of two isolates of Phytophthora ramorum.

\begin{tabular}{|c|c|c|c|c|}
\hline \multirow{3}{*}{ Compounds } & \multirow{3}{*}{$\mathbf{n}$} & \multicolumn{3}{|c|}{ MIC* (mmol) against $P$. ramorum } \\
\hline & & \multicolumn{2}{|l|}{ Assay 1} & \multirow{2}{*}{$\begin{array}{l}\text { Assay } 2 \\
\text { BRC01 }\end{array}$} \\
\hline & & $\overline{\text { BRC01 }}$ & P1578 & \\
\hline Acetovanillone + water & 3 & 1.6 & 1.6 & 1.6 \\
\hline Acetovanillone + DHAA & 3 & 0.2 & 0.2 & 0.2 \\
\hline Acetovanillone + AA & 3 & - & - & 0.1 \\
\hline Acetovanillone + PA & 3 & - & - & 1.6 \\
\hline Coniferaldehyde + water & 3 & 0.15 & 0.15 & 0.1 \\
\hline Coniferaldehyde + DHAA & 3 & 0.02 & 0.02 & 0.02 \\
\hline Coniferaldehyde + AA & 3 & - & - & 0.02 \\
\hline Coniferaldehyde + PA & 3 & - & - & 0.11 \\
\hline Vanillin + water & 3 & 1.52 & 1.52 & 1.5 \\
\hline Vanillin + DHAA & 3 & 0.38 & 0.38 & 0.38 \\
\hline Vanillin + AA & 3 & - & - & 0.38 \\
\hline Vanillin + PA & 3 & - & - & 1.5 \\
\hline
\end{tabular}

* MIC was the same for each replicate

This article is protected by copyright. All rights reserved. 
Table 7 Effect of heat-treated woodchips of larch, rhododendron and pine tested in the field on the survival of natural inoculum of Phytophthora ramorum. After harvesting each treatment replicate was baited with 30 rhododendron leaf disks per sample to test for the presence of viable P. ramorum.

\begin{tabular}{|c|c|c|c|c|c|c|c|c|}
\hline \multirow{3}{*}{ Treatments } & \multirow{3}{*}{$\mathbf{n}$} & \multicolumn{6}{|c|}{ Sampling intervals } & \multirow{3}{*}{$\begin{array}{l}\text { Significa } \\
\text { nce } \\
\text { air- } \\
\text { dried vs } \\
\text { heat- } \\
\text { treated }\end{array}$} \\
\hline & & \multicolumn{2}{|c|}{$4,8,12$ weeks } & \multicolumn{2}{|c|}{20 weeks } & \multicolumn{2}{|c|}{52 weeks } & \\
\hline & & $\begin{array}{l}\text { Air- } \\
\text { dried }\end{array}$ & $\begin{array}{l}\text { Heat- } \\
\text { treated }\end{array}$ & $\begin{array}{l}\text { Air- } \\
\text { dried }\end{array}$ & $\begin{array}{l}\text { Heat- } \\
\text { treated }\end{array}$ & $\begin{array}{l}\text { Air- } \\
\text { dried }\end{array}$ & $\begin{array}{l}\text { Heat- } \\
\text { treated }\end{array}$ & \\
\hline $\begin{array}{l}\text { Japanese larch (Larix } \\
\text { kaempferi) }\end{array}$ & 18 & 0.0 & 0.0 & 0.0 & 0.0 & $\begin{array}{l}13.5 \\
\pm 5.0\end{array}$ & $\begin{array}{l}3.1 \pm \\
2.1\end{array}$ & $p<0.001$ \\
\hline $\begin{array}{l}\text { Scots pine (Pinus } \\
\text { sylvestris) }\end{array}$ & 18 & 0.0 & 0.0 & 0.0 & 0.0 & $\begin{array}{l}16.1 \\
\pm 2.9\end{array}$ & $\begin{array}{l}3.8 \pm \\
2.5\end{array}$ & $p<0.001$ \\
\hline $\begin{array}{l}\text { Rhododendron } \\
\text { (Rhododendron } \\
\text { ponticum) }\end{array}$ & 18 & 0.0 & 0.0 & $\begin{array}{l}2.8 \pm \\
1.8\end{array}$ & 0.0 & $\begin{array}{l}16.1 \\
\pm 5.0\end{array}$ & $\begin{array}{l}8.5 \pm \\
3.3\end{array}$ & $p>0.05$ \\
\hline
\end{tabular}

This article is protected by copyright. All rights reserved. 


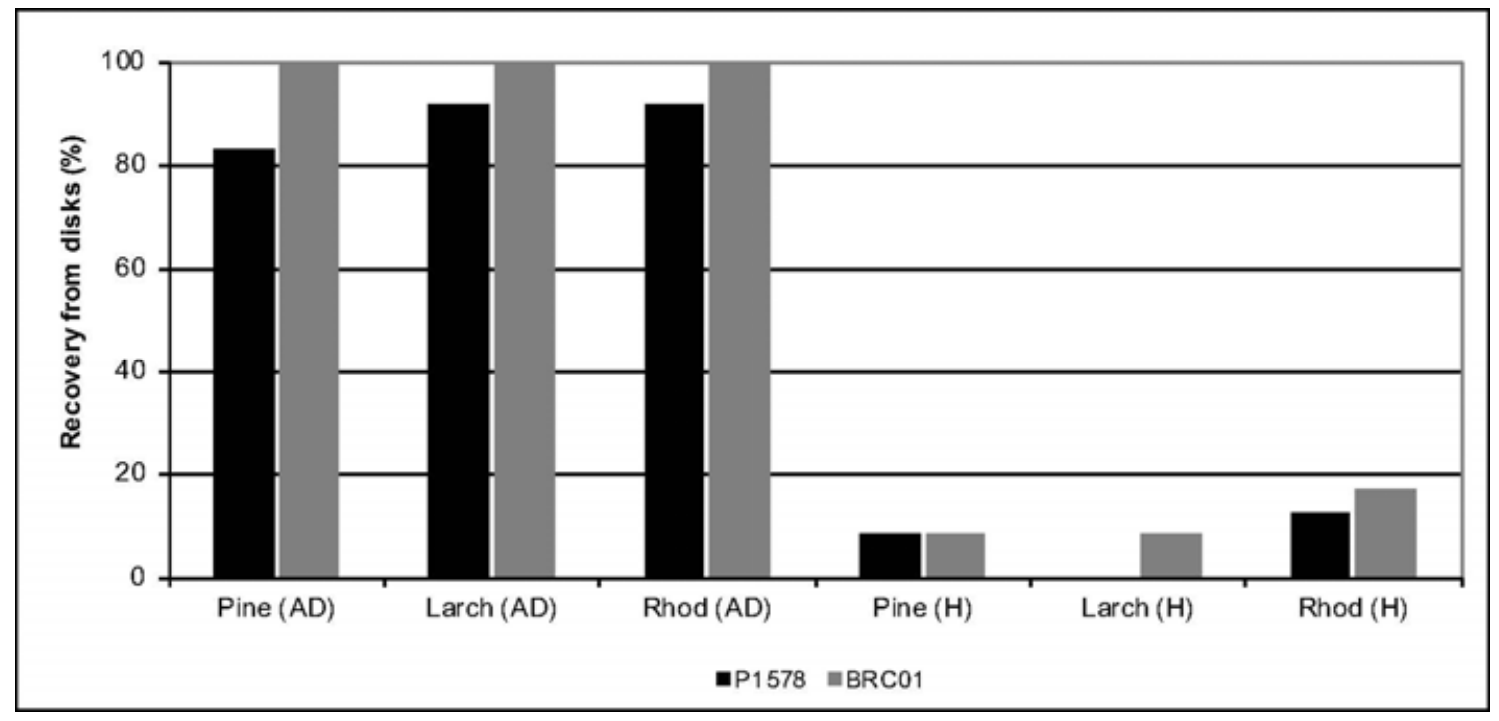

This article is protected by copyright. All rights reserved. 

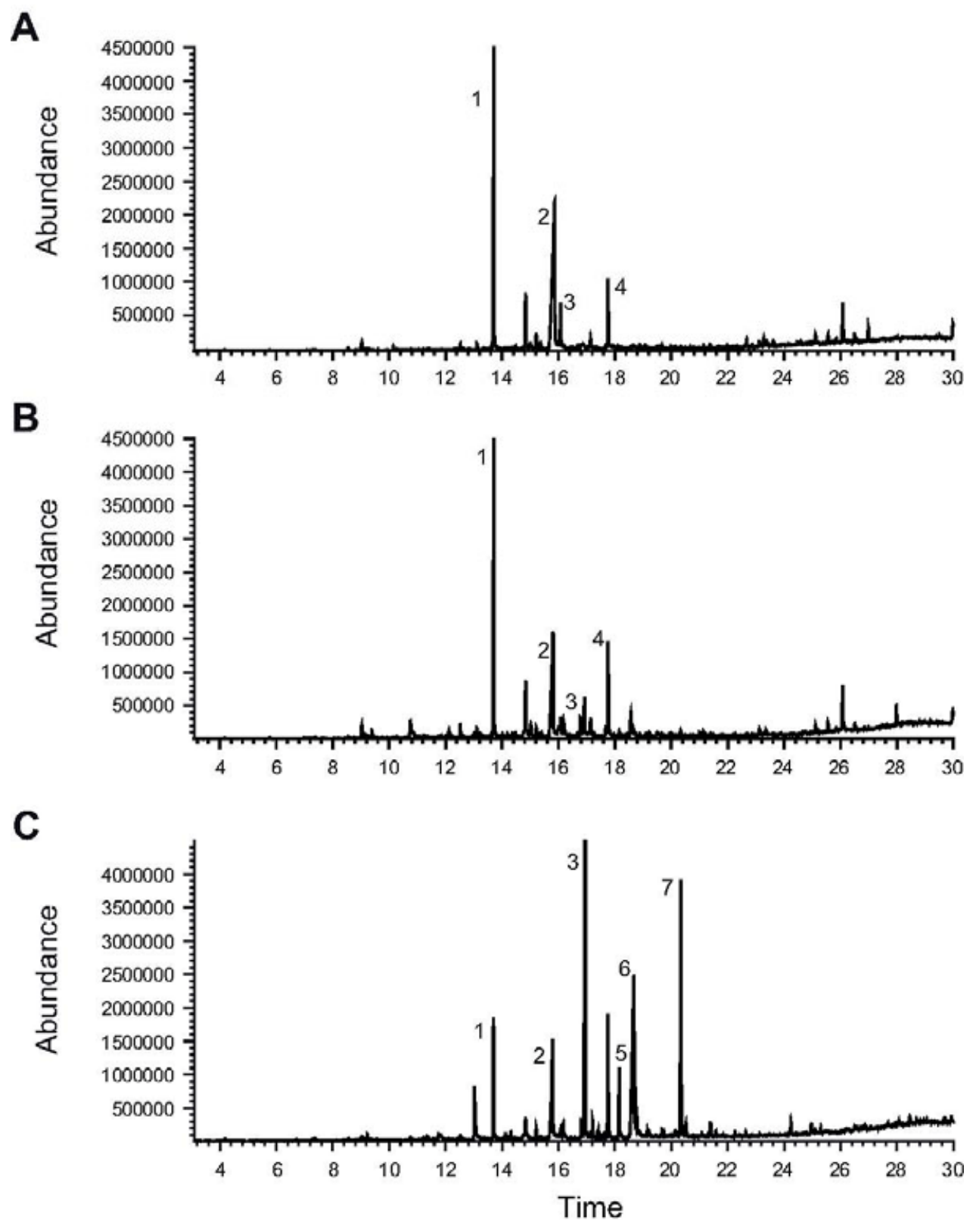

This article is protected by copyright. All rights reserved. 
A

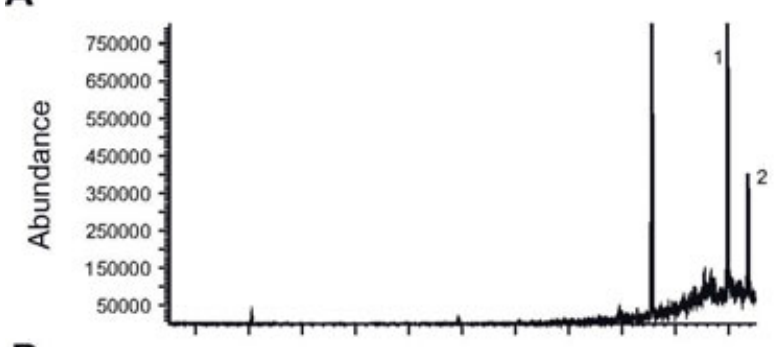

B

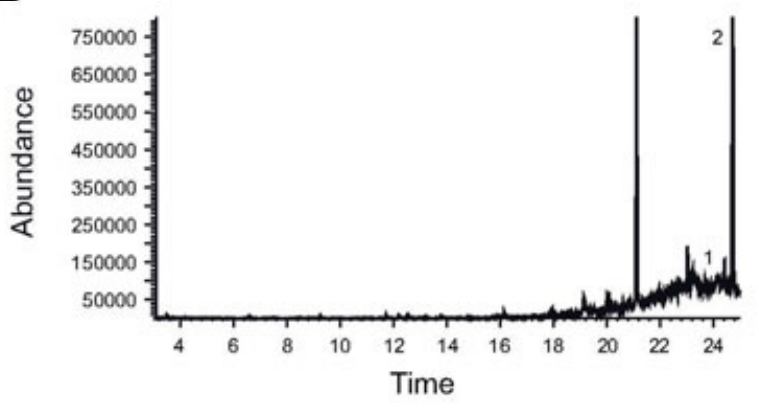

C

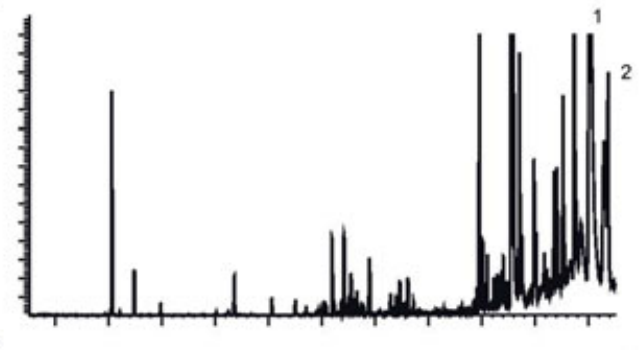

D



This article is protected by copyright. All rights reserved. 